\title{
PROBLEMATIKA PENDIDIKAN ISLAM
}

Oleh : Andi Makmur Jaya Nur ${ }^{1}$

$* * *$

\begin{abstract}
Abstrak
Pendidikan adalah usaha sadar yang dilakukan oleh orang dewasa kepada generasi muda untuk melestarikan nilai-nilai yang lebih baik. Dengan demikian, pola pendidikan pun berkembang sesuai dengan tuntutan zaman. Hanya saja, pada sepanjang perjalanan pendidikan mengalami problematika yang semakin kpmpleks ; termasuk pendidikan Islam. Problematika pendidikan Islam adalah menjawab tantangan peradaban yang semakin berkembang yang ditandai dengan munculnya masa yang disebutkan oleh Harold G. Shane sebagai masa depan sosio, masa depan tekno, dan masa depan bio. Sampai satu dasawarsa terakhir dunia pendidikan Islam belum sepenuhnya dapat memenuhi harapan masyarakat, fenomena itu ditandai dari rendahnya mutu lulusan, sehingga pendidikan Islam dituntut memperbaiki manajemen penyelenggarannya
\end{abstract}

Kata Kunci: Problematika, pendidikan

\section{PENDAHULUAN}

A gama Islam yang diwahyukan kepada Nabi Muhammad Saw, $\triangle$ mengandung implikasi kependidikan yang bertujuan untuk menjadi 1 rahmat bagi sekalian alam. Agama Islam mengandung suatu potensi yang mengacu kepada dua fenomena perkembangan, yaitu :

1. Potensi psikologi dan pedagogis yang memengaruhi manusia untuk menjadi sosok pribadi yang berkualitas bijak dan menyandang derajat mulia melebihi makhluk-makhluk lainnya.

2. Potensi pengembangan kehidupan manusia sebagai khalifah di muka bumi yang dinamis dan kreatif serta responsif terhadap lingkungan sekitarnya, baik yang alamiah maupun yang ijtimaiah dimana Tuhan menjadi potensi sentral perkembangannya.

Untuk mengaktualisasikan dan memfungsikan potensi tersebut di atas, diperlukan ikhtiar kependidikan yang sistematis-berencana berdasarkan pendekatan dan wawasan yang interdisipliner. Penyebabnya, manusia semakin terlibat ke dalam proses perkembangan masyarakat yang semakin kompleks.

\footnotetext{
${ }^{1}$ Dosen STAIM Sinjai
} 
Kompleksitas perkembangan sosial itu sendiri menunjukkan adanya interelasi dari berbagai aspek kepentingan. ${ }^{2}$

Berangkat dari hal tersebut, proses kependidikan Islam memerlukan konsep-konsep yang pada gilirannya dapat dikembangkan menjadi teori-teori yang teruji di lapangan operasional. Bangunan teoritis kependidikan Islam itu akan dapat berdiri tegak di atas pondasi pandangan dasar (filosofi) yang telah digariskan oleh Tuhan dalam kitab suci Al-Quran. Melalui teori pendidikan Islam itulah, para pendidik muslim akan mengembangkan konsep-konsep baru sesuai dengan tuntutan zaman, sehingga pendidikan Islam akan terus berkembang mengacu kepada tuntutan masyarakat yang berkembang secara dinamis konstruktif menuju masa depan yang lebih sejahtera dan maju. ${ }^{3}$

Untuk mencapai maksud tersebut maka al-Khailani mengatakan bahwa pendidikan Islam harus selalu mengacu kepada penemuan kebutuhan-kebutuhan manusia dan masyarakat muslim khususnya. Oleh karena itu, manajemen pendidikan Islam harus diperbaiki sedemikian rupa; di samping penyusunan kurikulum yang sesuai dengan asas Islam harus dikembangkan terus menerus sehingga sesuai dengan kebutuhan masyarakat.

A K Modawi dalam thesisnya mengemukakan bahwa pendidikan barat yang selama ini diklaim sebagai pendidikan sekularisme ternyata banyak ajaranajaran agama Islam (al quran) yang dipraktekkan dalam kehidupan mereka, sehingga apabila umat Islam ingin maju khususnya di bidang pendidikan harus bercermin kepada Barat dengan tidak meninggalkan ajaran Al-Quran. ${ }^{4}$

Dalam lintasan sejarah Islam disebutkan bahwa pendidikan pada masa Rasulullah Saw, dianggap berhasil karena mereka konsisten terhadap ajaran AlQuran. Di samping itu, Rasul sebagai penyampai ajaran Islam menjadikan dirinya sebagai contoh teladan bagi umatnya, sehingga pada waktu itu terkenallah tokohtokoh pendidik pada zaman Rasul yang tidak diragukan kapasitas keilmuannya seperti, para Khulafaur Rasisyidin, Ibnu Abbas, Muaz bin Jabal, Aisyah r a, dan lain-lain.

Di zaman sekarang, pendidikan Islam mengalami penurunan kualitas alumni yang dihasilkan dibanding pada zaman keemasan Islam. Bahkan lebih jauh, problem pendidikan hari ini adalah relevansi output pendidikan dengan dunia kerja. Pendidikan dikatakan berhasil manakala output pendidikan dapat terserap dalam bursa kerja. Sebaliknya, pendidikan dikatakan gagal manakala tidak dapat mengantar outputnya ke dalam dunia kerja. Jelas hal ini sedikit

${ }^{2}$ M. Arifin, Kafita Selekta Pendidikan Islam dan Umum ( Cet. IV, Jakarta : Bumi Aksara, 2000), h. 2

${ }^{3}$ Ibid, h. 3

${ }^{4}$ Abdurahman Shaleh Abdullah, Teori-teori Pendidikan berdasrkan Al-quran, (Cet. II, Jakarta : Rineka Cipta, 994), h. 11 
banyaknya akan berdampak pada penajaman aspek moralitas. Moral tidak menjadi "kebanggaan" manakala tidak memiliki kemampuan kompetetif dalam dunia kerja. Hal tersebut menjadi problematika bagi umat Islam di masa sekarang untuk dipecahkan dan dicarikan jalan keluar, agar pendidikan Islam mampu berkompetisi dan bersaing dengan pendidikan Barat yang notabene mengesampingkan muatan ukhrawi.

\section{PEMBAHASAN}

\section{A. Problematika Pendidikan Islam Masa Kini}

Pendidikan adalah suatu proses yang berkelanjutan tempat suatu bangsa atau negara membina dan mengembangkan kesadaran diri di antara individuindividu warganya. Adanya kesadaran tersebut, suatu bangsa atau negara dapat mewariskan kekayaan budaya atau pemikiran kepada generasi berikutnya, sehingga menjadi inspirasi bagi mereka dalam setiap aspek kehidupan.

Oleh karena itu, pendidikan benar-benar merupakan latihan fisik, mental, dan moral bagi individu-individu, supaya mereka menjadi manusia yang berbudaya, sehingga mampu memenuhi tugasnya sebagai manusia dan menjadi warga negara yang berarti bagi suatu negara. Apabila dihubungkan dengan pegertian pendidikan Islam, maka tujuan pendidikan adalah untuk membentuk manusia seutuhnya, akal dan hatinya, rohani dan jasmaniya, akhlak dan Aqidahnya serta ilmu dan keterampilannya. ${ }^{1}$

Untuk mencapai hal tersebut, maka pendidikan Islam sekarang harus segera berbenah diri dalam arti segera memperbaiki srtuktur, manajemen atau lembaga pendidikan Islam. Sebab perkembangan dan arus informasi sekarang, hampir sudah terjangkau ke pelosok-pelosok desa ; menyebabkan pergeseran paradigma masyarakat tentang arti lembaga pendidikan yang berkualitas. Kalau pendidikan Islam tidak dimenej dengan baik, dan dikelola oleh tangan-tangan yang terampil, maka cepat atau lambat mereka pasti akan gulung tikar dan tujuan pendidikan Islam pun tidak akan tercapai dengan baik. Dalam hal ini, berbagai macam problem pendidikan Islam yang menghadang harus segera dibenahi, agar pendidikan masa sekarang dapat menjadi bekal buat pendidikan hari esok. Di antara probem tersebut adalah :

1. Sistem pendekatan dan orentasi.

Di tengah gelombang krisis nilai-nili kultural akibat pengaruh ilmu dan teknologi yang berdampak pada perubahan sosial, pendekatan pendidikan Islam yang memandang bahwa kebenaran Islam yang mutlak pasti mampu mengalahkan kebatilan yang merajalela di luar kehidupan Islam dengan dasar dalil (jika datang

${ }^{1}$ Azyumardi, Esei-Esei Intelektual Muslim dan Pendidikan Islam, (Cet. I, Jakarta : PT. Logos Wacana ilmu, 1999), h. 4 


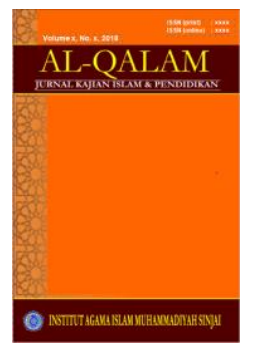

\section{AL-QALAM}

Jurmal Kajian Islam \& Pendidikan

Volume 06 No 022014

ISSN (print) : 1858-4152

ISSN (online) : -

Homepage : http://journal.iaimsinjai.ac.id/index.php/al-qalam

perkara yang haq maka hancurlah yang batil) perlu dilakukan modifikasi/perubahan menjadi pendekatan yang berdasarkan atas pandangan yang realistis ; bahwa Islam sebagai suatu kebenaran mutlak baru mampu berkembang dengan sepenuhnya dalam masyarakat bila para pendukungnya berusaha keras dan tepat sasaran melalui sistem dan metode yang efektif dan efisien. ${ }^{2}$ Efektifitas dan efisiensi pendidikan Islam menuntut kita untuk menerapkan pelbagai rekayasa yang didasari oleh ilmu pengetahuan teoritis dan praktis sesuai dengan sasaran yang digarap.

Pendidikan Islam masa kini dihadapkan kepada tantangan yang jauh lebih berat dari tantangan yang dihadapi pada masa permualaan penyebaran Islam. Tantangan tersebut berupa timbulnya aspirasi dan idealitas umat manusia yang serba multi-interest yang berdimensi nilai ganda dengan tuntutan hidup yang multi kompleks pula. Jadi, tugas pendidikan Islam dalam proses pencapaian tujuannya tidak lagi menghadapi problema kehidupan yang simplisistis, melainkan amat kompleks akibat rising demand manusia semakin kompleks pula. Semakin kompleks akibat demand, semakin kompleks pula hidup kejiwaannya, sehingga manusia sukar menerima nafas keagamaan.

Oleh karena itu, diperlukan sistem dan metode yang menarik. Orentasi pendidikan Islam dalam zaman teknologi masa kini dan masa depan perlu diubah, yang semula berorentasi kepada kehidupan ukhrawy menjadi duniawi ukhrawi secara bersamaan. Orientasi ini menghendaki suatu tujuan rumusan pendidikan yang jelas, karena itu program pembelajarannya harus lebih diproyeksikan ke masa depan dari pada masa kini atau masa lampau. Meskipun masa lampau dan masa kini tetap dijadikan khazanah kekayaan empiris yang amat berharga bagi batu loncatan ke masa depan, sehingga nostalgia ke masa keemasan dunia Islam masa lampau tidak perlu lagi mengobsesi pemikiran kita. ${ }^{3}$

Kondisi seperti ini semakin diperparah ketika pendidikan Islam dihadapkan untuk menghadapi pergeseran nilai-nilai kultural-tradisional dari dunia kehidupan yang belum menemukan permukiman yang mapan. Pendidikan Islam dituntut untuk menerapkan pendekatan dan orentasi baru yang relevan dengan tututan zaman, sehingga pendidikan Islam mampu menjawab trend perubahan sosio-kultural masyarakat masa kini.

2. Pelembagaan proses kependidikan Islam .

Pendidikan Islam yang berlangsung melalui proses operasional menuju tujuannya memerlukan model dan sisitem yang konsisten yang dapat mendukung nilai-nilai moral spritual yang melandasinya.

\footnotetext{
${ }^{2}$ M. Arifin, op. cit, h. 5

${ }^{3}$ Ibid, h. 5 dan lihat Ahmad Tafsir, Ilmu Pendidikan dalam perspektif Islam, (Cet. III, bandung : Remaja Rosdakarya, 2000), h. 116
} 
Nilai-nilai tersebut diaktualisasikan berdasarkan orentasi kebutuhan perkembangan fitrah peserta didik (learner's potentials orentation) yang dipadu dengan pengaruh lingkungan kultural yang ada. Oleh karena itu, manajemen kelembagaan pendidikan Islam memandang bahwa seluruh proses kependidikan dalam institusi adalah sebagai suatu sistem yang berorentasi kepada perbuatan yang nyata (action oriented syistem) berdasarkan atas pendekatan sistematik.

Kelembagaan pendidikan Islam merupakan subsistem dari sistem masyarakat atau bangsa. Operasionalisasinya selalu mengacu dan tanggap kepada kebutuhan perkembangan masyarakat. Tanpa bersikap demikian, lembaga pendidikan kita dapat menimbulkan kesenjangan sosial dan kultural. Kesenjangan inilah yang menjadi salah satu sumber komflik antara pendidikan dan masyarakat. Dari sanalah sebuah krisis kependidikan yang intensitasnya berbeda-beda menurut tigkat atau taraf rising demands masyarakat. ${ }^{5}$

Jalan untuk mengetahui adanya kesenjangan antara adanya lembaga pendidikan dan masyarakat yang berkenaan dengan kebutuhan yang meningkat adalah dengan melakukan assessment. Hal ini akan mendesak pendidikan Islam untuk melakukan inovasi secara komprehensip pada seluruh komponen pendidikan. Apalagi para kritikus dan pakar melontarkan berbagai pandangan kritis, bahkan pandangan sinis terhadap posisi lembaga pendidikan Islam sebagai lembaga pendidikan yang "tak berdaya" 6

Pandangan ilmuan dari berbagai disiplin ilmu, ada yang mengangggap bahwa sekolah Islam terlalu monopolis-etis tidak lagi humane atau populis, sistemnya sudah usang, lapuk dan rapuh, tak berdaya dalam adaptasi modernisasi masyarakat, bahkan ada yang menganggap bahwa sekolah Islam tidak lagi dipersamakan dengan mental blenders, yang membingungkan masyarakat dan sebagainya.

Di samping itu pergeseran idealitas masyarakat yang menuju ke arah pola pikir rasional-teknologis yang cenderung melepaskan diri dari tradisionalisme kultural-eduktif semakin membengkak. Fungsi lembaga kependidikan Islam harus bersifat laten terhadap kecenderungan sosial, sehingga kemelut yang terjadi di dalam masyarakat yang purna-industri terutama di Barat dapat dinetralisir.

Oleh karena itu, lembaga pendidikan Islam harus bangkit dan sadar bahwa lembaga pendidikan Islam hari ini masih bersikap konservatif dan statis, sehingga tidak memiliki kepekaan untuk menyerap tendensi dan aspirasi masyarakat ; bahkan masyarakat tradisional sekalipun. Pendidikan Islam perlu memacu diri untuk melakukan inovasi dalam wawasan, stategi dan program-programnya

${ }^{5} \mathrm{M}$. Arifin op. cit, h. 6

${ }^{6}$ Lihat lebih lanjut M. Mulyasa, Kurikulum Bebasis Kompetensi, Konsep, Karakteristik dan Inplemaentasi, (cet. III, Bandung : Remaja Rosdakarya, 2003), h. 9

${ }^{7}$ M. Arifin, op. cit, h. 8 


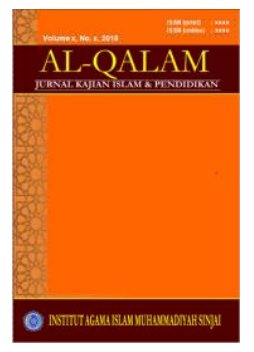

AL-QALAM

Jurnal Kajian Islam \& Pendidikan

Volume 06 No 022014

ISSN (print) : 1858-4152

ISSN (online) : -

Homepage : $\underline{\text { http://journal.iaimsinjai.ac.id/index.php/al-qalam }}$

sedemikian rupa, sehingga mampu menjawab secara aktual dan fungsional semua tantangan baru. Apalagi bila diingat bahwa misi pendidikan Islam lebih berorientasi kepada nilai-nilai luhur dari Tuhan yang harus diinternalisasikan ke dalam lubuk hati tiap pribadi manusia melalui bidang-bidang kehidupan manusia ; membawa pendidikan Islam untuk melakukan pendekatan sistemik yang bersifat missionair yang mengedepankan faktor humanisasi sebagai strategi sentral. ${ }^{8}$

3. Pengaruh sains dan teknologi canggih

Dampak dari teknologi sekarang ini bersifat fasilitatif (memudahkan) kehidupan manusia yang sibuk menangani berbagai problem yang semakin membelilit. Teknologi menawarkan berbagai macam kesantaian dan kesenangan yang semakin beraneka, memasuki ruang-ruang dan cela-cela kehidupan umat Islam.

Dampak negatif dari teknologi modern telah mulai menampakkan diri di depan mata yang pada prinsipnya berkekuatan untuk melemahkan daya mental spritual/jiwa yang sedang tumbuh dan berkembang dalam berbagai bentuk penampilan dan gayanya. Tidak hanya nafsu muthmainnah yang dapat diperlemah oleh rangsangan negatif dari teknologi elektronis dan informatika, melainkan juga fungsi-fungsi kejiwaan lainnya seperti kecerdasan, ingatan kemauan dan perasaan (emosi). Kemampuan aktual diperlemah dengan adanya alat-alat teknologiselektronis dan informatika seperti komputer, foto copy jarak jauh, Video Casettet Recorder (VCR) dan komediti celluloid (film, vidio disc.) dan sebagainya. ${ }^{9}$

Anak didik tidak perlu lagi belajar bahasa asing atau keterampilan tangan dan berpikir ilmiah taraf tinggi karena alat-alat teknologi telah mampu menggantikannya dengan komputer penerjemah semua bahasa asing, robot-robot telah siap mengerjakan tugas-tugas yang harus dikerjakan dengan tangan dan mesin otak komputer generasi baru yang mampu berpikir lebih cepat dari otak manusia sendiri. Lalu bagaimana tentang proses menginternalisasikan dan mentrasformasikan nilai-nilai iman dan taqwa ke dalam lubuk hati manusia? Sementara sampai saat ini belum terdengar adanya teknologi trasformasi nilainilai spritual melalui alat teknologi canggih tersebut. ${ }^{10}$

Bertolak dari fenomena tersebut, permasalahan baru yang harus dipecahkan oleh pendidikan Islam antara lain dehumanisasi pendidikan, netralisasi nilai-nilai agama, atau upaya mengendalikan dan mengarahkan nilai-nilai tradisional kepada nilai-nilai ilahiah yang kokoh dan tahan banting, baik dalam dimensi individual maupun sosiokultural.

8 ibid, h.

${ }^{9}$ ibid, h. 9 dan lihat pula Burhan Bungin, Erotika Media Massa, (Cet.I, Surakarta, Muhammadiyah University Perss, 2001), h. 12

${ }^{10}$ Azyumardi Azra, op. cit, h. 169 


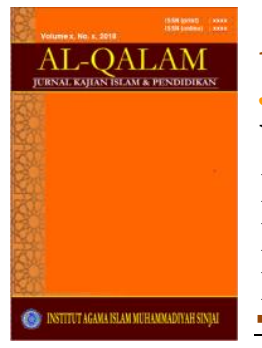

AL-QALAM

Jurnal Kajian Islam \& Pendidikan

Volume 06 No 022014

ISSN (print) : 1858-4152

ISSN (online) : -

Homepage : $\underline{\text { http://journal.iaimsinjai.ac.id/index.php/al-qalam }}$

Di arena pembenturan antarnilai sekuler dan nilai absolutisme dari Tuhan akibat rentannya pola pikir manusia yang teknologis-pragmatis relativistik inilah pendidikan Islam harus hidup berdampingan dan membuktikan kemampuan kecanggihannya. Di sinilah to be or not to be-nya (eksistensinya) pendidikan Islam. ${ }^{11}$

Tuntutan masyarakat industri teknologis masa kini dan masa datang adalah seperti yang digambarkan oleh skinner, pelopor pendidikan dan teknologis behavioris mengatakan bahwa pendidikan saat ini hanya dijadikan sebagai cabang dari teknologi ilmiah yang paling penting, yang sangat berpengaruh terhadap kehidupan manusia, padahal seharusnya pendidikan harus dijadikan pusat-pusat pengembangan peradaban dan kebudayaan umat manusia dalam masyarakat.

Kekeliruan pandangan demikian memang beralasan karena lembaga pendidikan Islam dalam beberapa seginya seharusnya dijadikan sumber pengembangan sains dan teknologi. Akan tetapi kenyataanya tidak. Justru pendidikan Islam tertinggal dalam hal sains dan teknologi. Bahkan beberapa di antaranya masih resisten dengan sanis dan teknologi. Padahal idealnya, pendidikan Islam harus inheren dengan sains dan teknologi agar proses pendidikan yang berlangsung dapat mencapai output yang seirama dengan kemajuan teknologi itu sendiri. Hal ini penting untuk menghindari penetrasi pandangan pragmatisme yang menganggap bahwa nilai-nilai apapun tidak diperlukan karena sains dan teknologi bebas dari nilai apapun, baik nilai moral maupun nilai spritual.

Namun demikian, aliran behaviorisme masih menghargai sekolah selaku lembaga pendidikan yang berdaya guna. Sekolah masih anggap sebagai basis pendidikan yang harus berperan serta untuk membawa manusia kepada tujuan hidupnya. Hanya saja sekolah sebagai lembaga pendidikan harus mau menerima kenyataaan bahwa revisi secara menyeluruh mengenai praktek-praktek pendidikan dan kependidikan adalah sebuah keharusan. Hanya dengan jalan itu sekolah dapat diharapkan sebagai suatu sistem yang mampu memenuhi ciri-ciri dan watak dari tugasnya untuk menjamin metode-metodenya dan secara sukarela disupport oleh warga negara yang efektif dan berpengetahuan untuk mencetak manusia-manusia unggul. ${ }^{12}$ Jelas, dalam konteks ini, sekolah-sekolah Islam termasuk di dalamnya.

4. Perencanaan dan model-model pendidikan Islam.

Kebutuhan pendidikan biasanya diukur dari adanya kesenjangan antara Das sein dengan Das Sollen dari hasil yang dicapai dengan hasil yang seharusnya dicapai. Menurut beberapa ilmuan bidang pendidikan antara lain Roger A. Kaufgman, mengatakan untuk menganalisis kesenjangan antara hasil yang ada dengan hasil yang seharusnya ada, yang disebut descrepancy analysis atau need

\footnotetext{
${ }^{11}$ M. Arifin, op. cit, h. 9

12 ibid, h. 10
} 


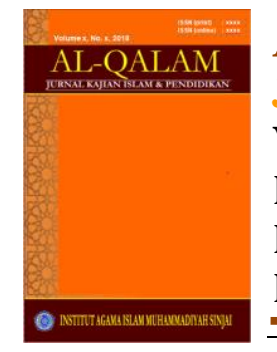

AL-QALAM

Jurnal Kajian Islam \& Pendidikan

Volume 06 No 022014

ISSN (print) : 1858-4152

ISSN (online) : -

Homepage : http://journal.iaimsinjai.ac.id/index.php/al-qalam

assessment perlu memasukkkan ketiga pemeran serta (educational partners) kependidikan, yaitu siswa, orang tua atau anggota masyarakat dan para pendidik (guru) sebagai pelaksana proses kependidikan. ${ }^{13}$

Dengan cara demikian dapat diketahui tingkat kebutuhan kependidikan (seperti ilmu pengetahuan, sikap dan keterampilan) anak didik. Dimensi-dimensi kebutuhan tersebut ditetapkan setelah mengidentifikasi tingkat dan macam kebutuhan kependidikan apa dari ketiga aspek tuntutan, yaitu masyarakat, siswa dan pendidik (guru).

Dalam sejarah perkembangan Islam pada priode awal, pendidikan Islam yang telah dilaksanakan oleh Nabi Muhammad Saw, adalah pemenuhan kebutuhan manusia untuk bebas dari belenggu akidah yang sesat yang dianut oleh kelompok elitis Quraisy dan yang dijadikan sarana mental untuk melestarikan kekuasaan penindas terhadap orang-orng dari kelompok lain yang dipandang rendah derajatnya. Islam dengan ajaran tauhidnya yang diinternalisasikan oleh Nabi secara individu dapat membersihkan kepercayaan sesat itu dari jiwa mereka, sehingga tauhid menjadi landasan kokoh dalam kehidupan manusia. ${ }^{14}$

Metode yang dipergunakan Nabi adalah personalisasi berdasarkan pendekatan personal individual, kemudian meluas ke arah pendekatan keluarga yang pada gilirannya meluas ke arah pendekatan sosiologis (masyarakat). Pendekatan personal, keluarga, dan masyarakat tersebut merupakan proses ke arah pendekatan sistemik yang memandang bahwa orang perorang merupakan bagian dari unit keluarga, sedang keluarga menjadi subsistem masyarakat dan masyarkat semakin berkembang menjadi makro sistem dalam bentuk negara.

Kebutuhan pendidikan yang prioritas dalam pendidikan Islam masa itu adalah penanaman aqidah tauhid yang berproses selama 10 tahun priode Makkah. Kemudian disusul dengan pembinaan masyarakat amaliyah pada priode Madinah selama 10 tahun lebih. Dalam priode ini pendidikan Islam menyertakan peranan sanksi-sanksi hukuman dan ganjaran pada individu dan masyarakat atas tanggung jawab pengamalan ajaran Islam. ${ }^{15}$

Jadi, tampaklah bahwa pendekatan sistemik Islam dari Nabi pada proses awalnya berdasarkan hikmah dan mauizdatil hasanah dengan metode taghrib dan tarhieb yang dramatisasikan dalam bentuk uswatun. Meskipun pada zaman Nabi memimpin masyarakat Madinah dan Mekkah tidak ada sekolah formal seperti saat ini, namun pendidikan Islam secara institusional telah berproses secara mapan dengan embrio model pendidikan halaqah di Masjid dan al-Haram dan zawiyah di

\footnotetext{
${ }^{13}$ Lihat lebih lanjut, Ahmad Tafsir, op.cit, h. 155

${ }^{14}$ M. Arifin, op. cit, h. 10

${ }^{15}$ lihat Ahmad Tafsir, op. cit, h. 186
} 


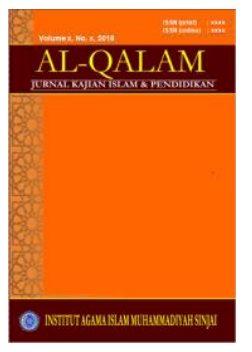

AL-QALAM

Jurnal Kajian Islam \& Pendidikan

Volume 06 No 022014

ISSN (print) : 1858-4152

ISSN (online) : -

Homepage $: \underline{\text { http://journal.iaimsinjai.ac.id/index.php/al-qalam }}$

sudut masjid. Kemudian muncul model pendidikan Majelis Ta'lim Dar al arqam, dibarengi dengan berdirinya kuttab-kuttab bagi anak-anak untuk belajar al-quran ${ }^{16}$

Dari segi manajmen kependidikan, suatu perencanaan untuk pendidikan masa depan harus meliputi tiga ciri pokok masyarakat menurut Herold G. Shane salah seorang futuris yang optimis, yaitu masa depan sosio, masa depan tekno, dan masa depan bio, memiliki implikasi dan dampak terhadap jiwa manusia. Ketiga hal tersebut adalah :

a. Masa depan sosio ; yang mengandung fenomena prinsipal antara lain penyaebaran alternatif struktur rumah tangga yang lambang, sharing childrearing (pengasuhan anak oleh orang tuanya), pandangan tentang posisi keibuan, hubungan-hubungan seksualitas dan moralitas sosial baru serta interpretasi kembali tentang peranan agama dalam masyarakat.

b. Masa depan tekno; secara singkat dapat disimpulkan bahwa masayarakat masa depan akan dilanda pengaruh energi fisika tinggi, inovasinya dan inflikasinya yang cendrung lebih besar terhadap energi sinar laser; bidang sibernetika, proses kontrol sistem-sistem mekanik, biologi dan elektronik makin dimurnikan pemakaiannya, terjadinya perubahan terhadap media massa, seperti TV, proyeksi tiga dimensi dengan menggunakan sinar laser, adanya sukses besar dalam manipulasi dan sertorasi lingkungan, pengurangan tenaga kerja, penyempunaan energi solar dan nuklir, peningkatan penggunaan komputer dan teknik pemrosesan data, penyempurnaan komputer rumah tangga, pengenalan super konduktor pada trasmisi kelistrikan dan pengenalan tenaga non kabel dan lain-lain.

c. Masa depan bio; secara prinsipal ditandai dengan makin menghangatnya diskusi tentang pemakaian listrik modifikasi behavioral seperti kimia, elektronik dan kejiwaan serta isu-isu manipulasi genetika, akibat timbulnya hasrat ZPG, tugas-tugas keorangtuaan (parenthood) dan keibuan semakin selektif berdasarkan prinsif-prinsif genetika, teknik-teknik pengendalian kelahiran makin disempurnakan, menurunnya rentang hidup (life span) disebabkan oleh kekurangan makanan dan polusi lingkungan dan menurunnya tingkat kematian bayi secara mencolok, ilmu-ilmu hayat, ilmu biokimia, dan ilmu-ilmu tingkah laku seperti psikologi, besar kemungkinannya makin subur sedang fisika dan teknik akan kehilangan status oleh karena timbulnya kesadaran bahwa teknologi merupakan hikmah campuran (mixsed blessings). 17

Pada segi-segi penggambaran masa depan di atas, sesungguhnya idealitas pendidikan Islam dapat menjadi suatu kekuatan moral dan ideal bagi upaya

${ }^{16}$ Arkam Dhiyauddin Umari, Masyarakat Madani, Tinjauan Histories Kehidupan Nabi, (Cet. II, Jakarta : Gema Insani, 1999), h. 78

${ }^{17}$ M. Arifin, op. cit, h. 10 
pembudayaan, memanusiakan, dan mengagamakan manusia sesuai dengan petunjuk Allah Swt, dalam Q.S. Al Nisa (4), 9 sebagai berikut :

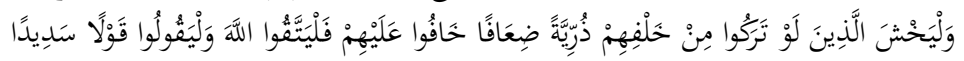

"Dan hendaklah takut kepada Allah orang-orang yang seandainya meninggalkan di belakang mereka anak-anak yang lemah, yang mereka khawatir terhadap (kesejahteraan) mereka. Oleh sebab itu hendaklah mereka bertakwa kepada Allah dan hendaklah mereka mengucapkan perkataan yang benar.

\section{B. Rancang Bangun Peningkatan Mutu Pendidikan Islam}

Globalisasi menuntut adanya perubahan paradigma dalam dunia pendidikan. Untuk melakukan hal tersebut, peranan manajemen pendidikan sangat signifikan untuk menciptakan sekolah-sekolah bermutu. Menurut Garfinkle kebutuhan terhadap paradigma baru pendidikan didasarkan atas perubahan besarbesaran dalam kondisi dan kebutuhan-kebutuhan pendidikan dalam masyarakat informasi.

Peningkatan kompetensi, pilihan dan tuntutan pelanggan pendidikan memengaruhi pendidikan hari ini. Pada saat bersamaan, faktor-faktor eksternal memengaruhi pendidikan nasional. Pendidikan perlu mendapat pengaturan dan standarisasi untuk memenangkan kompetensi dan peningkatan mutu terus menerus. Oleh karena itu, manajemen sekolah mengembangkan kreativitas, inovasi dan modernisasi bagi fokus bagi para pelanggan pendidikan, maka yang harus diperhatikan para menejer, kepala sekolah, guru-guru dan supervisor pendidikan adalah perbaikan mutu sebagai kunci sukses pendidikan di masa depan. ${ }^{18}$

Pada dasawarsa terakhir, dunia pendidikan belum mampu sepenuhnya memenuhi harapan masyarakat. Fenomena itu ditandai dari rendahnya mutu lulusan, penyelesaian masalah pendidikan yang tidak tuntas, atau cendrung tambal sulam, bahkan lebih berorentasi proyek. Akibatnya, sering hasil pendidikan mengecewakan masyarakat. Mereka terus mempertanyakan relevansi pendidikan dengan kebutuhan masyarakat dalam dinamika kehidupan ekonomi, politik, sosial, dan budaya. Kualitas lulusan pendidikan kurang sesuai dengan kebutuhan pasar tenaga kerja dan pembangunan, baik industri, perbankan, telekomunikasi maupun pasar tenaga kerja sektor lainnya yang cendrung menggugat eksistensi sekolah. Bahkan SDM yang disiapkan melalui pendidikan sebagai generasi belum

18 Syafaruddin, Manajemen Mutu Terpadu dalam pendidikan, konsep, strategi dan aplikasi, (Cet. I, Jakarta : Grasindo, 2002), h. 15 
sepenuhnya memuaskan bila dilihat dari segi akhlak, moral, dan jati diri bangsa dalam kemajemukan budaya bangsa. ${ }^{19}$

Kondisi tersebut menyebabkan sebagian masyarakat menjadi pesimis terhadap sekolah. Ada anggapan bahwa pendidikan tidak lagi mampu menciptakan mobilitas sosial mereka secara vertikal, karena sekolah tidak menjanjikan pekerjaan yang layak. Sekolah kurang menjamin masa depan anak yang lebih baik.

Pada abad ke XXI merupakan momentum yang penuh tantangan bagi negara sedang berkembang seperti Indonesia. Kita perlu mencari model baru manajemen pendidikan untuk menigkatkan mutu lulusan sekolah. Tak ada salahnya jika para pendidik mempelajari usaha-usaha di bidang pendidikan dalam berbagai dekade di negara-negara maju seperti di Amerika, Jepang dan Inggris. Negara-negara tersebut ketika itu merasa perlu menerapkan TQM (Total Quality Management) atau manajemen mutu terpadu dalam bidang pendidikan. Sebagai suatu sistem TQM tidak hanya mengikis problem pendidikan tetapi sekaligus sebagai model yang mengutamakan perbaikan berkelanjutan. ${ }^{20}$

Penulis berpendapat bahwa manajemen mutu pendidikan merupakan aplikasi konsep manajemen mutu yang disesuaikan dengan sifat dasar sekolah sebagai organisasi jasa kemanusiaan (pembinaan potensi pelajar). Aplikasinya terwujud melalui pengembangan pembelajaran berkualitas agar melahirkan lulusan yang sesuai dengan harapan orang tua, masyarakat, dan pelanggan pendidikan lainnya.

Bertolak dari hal tersebut di atas, maka manajemen pendidikan Islam yang bermutu dapat dicapai dengan memperhatian paling tidak empat hal, yaitu :

1. Pencapaian dan perumusan harapan pelanggan

Pemuasan harapan pelanggan ini berarti mengantisipasi kebutuhan pelanggan masa datang, mengambil resiko dan mengembangkan produk, serta melayani pelanggan yang tidak pernah mereka lihat, namun mereka suka dan membutuhkan. Seperti halnya di jepang dengan munculnya produk-produk berupa remot control bagi televisi, vidio record, faksimili dan lain-lain lebih awal.

Sallis mengatakan bahwa pendidikan yang termasuk pelanggan dalam adalah pegawai, pelajar dan orang tua pelajar. Sementara pelanggan luar mencakup akademi dan Universitas, bisnis, militer, dan masyarakat luas. Demikian pula lembaga pendidikan sekolah menegah pertama, sekolah menegah atas, dan perguruan tinggi. Hal ini penting untuk dikenali oleh pemimpin lembaga pendidikan atau kepala sekolah dan sumber daya personilnya untuk bekerja sama antara satu sama lainnya. Begitupula antara supervisor dan pelanggan produk,

\footnotetext{
${ }^{19}$ ibid, h. 19

${ }^{20}$ ibid, h. 36
} 


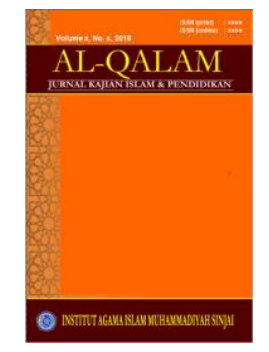

AL-QALAM

Jurnal Kajian Islam \& Pendidlikan

Volume 06 No 022014

ISSN (print) : 1858-4152

ISSN (online) : -

Homepage : http://journal.iaimsinjai.ac.id/index.php/al-qalam

sehingga dapat mengukur tingkat kepuasan para pelanggan pendidikan. ${ }^{21}$ Untuk mencapai hal tersebut, maka pendidikan beserta kelembagaannya harus berani melakukan inovasi dan peka terhadap perubahan sosial. Oleh karena itu, perencanaan pendidikan harus mulai dari identifikasi kebutuhan perkembangan anak didik seirama dengan perkembangan masyarakat.

2. Perbaikan terus menerus

Perbaikan terus menerus berarti merupakan tindakan pengejaran atas mutu yang prosesnya harus secara terus menerus diperbaiki ; diubah, ditambah, dikembangkan, dan dimurnikan. Oleh karena itu, tututan terhadap pelayanan terbaik juga menjadi perhatian bagi manajemen pendidikan Islam. Sekolahsekolah Islam pada dewasa ini tidak hanya cukup menawarkan program studi dengan kurikulum tertentu, tapi sekolah Islam juga harus menyediakan alat-alat belajar dan mengajar yang relevan dengan perkembangan zaman untuk mendukung kemajuan proses pembelajaran dan pengajaran. Gedung sekolah yang bagus diisi dengan sarana dan fasilitas belajar yang baik dan fungsional, tempat bermain pelajar, serta pelayanan yang prima terhadap pelajar, guru, orang tua dan masyarakat. Hal ini disebabkan situasi dan kondisi sekolah yang kondusif akan memberikan konstribusi positif bagi mutu produk lulusan sekolah. ${ }^{22}$

3. Pembagian Tanggung jawab dengan para pegawai

Pemberdayaan pegawai adalah hal yang sangat penting dalam perbaikan mutu. Oleh karena itu, perlu ada pembagian tanggung jawab sesama pegawai. Adapun guru-guru yang berpendidikan tinggi, berdedikasi dan bekerja keras merupakan orang yang seharusnya mengetahui bagaimana mereka belajar, para guru dan pegawai dapat diberdayakan sepenuhnya dengan memberi tanggung jawab dan keterampilan dalam rangka pencapaian manajemen pendidikan Islam bermutu. $^{23}$

Dengan demikian, seorang pendidik harus diberikan pekerjaan sesuai dengan profesinya, sehingga pekerjaan atau mata pelajaran yang dibebankan kepadanya dapat dipertanggungjawabkan. Pembagian tugas sesuai dengan keahliannya akan memberikan pengetahuan dan pengalaman baru bagi para peserta didik.

4. Pengurangan sisa pekerjaan dan pengerjaan ulang.

Dalam kegiatan pendidikan, seringkali pengelolaan sekolah bersifat kekeluargaan. Anak-anak yang tinggal kelas dipaksa untuk naik kelas, sehingga terhindar dari mengulang kelas. Padahal, pelajar-pelajar yang gagal untuk menguasai materi pengajaran harus mengulang pelajaran tersebut.

\footnotetext{
${ }^{21}$ ibid, h. 37

${ }^{22}$ Syafaruddin, op. cit, h. 38

${ }^{23} \mathrm{ibid}$, h.
} 


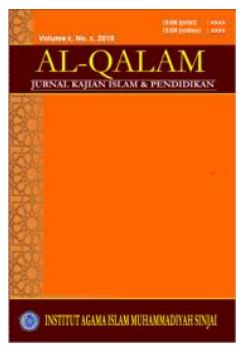

AL-QALAM

Jurnal Kajian Islam \& Pendidikan

Volume 06 No 022014

ISSN (print) : 1858-4152

ISSN (online) : -

Homepage : $\underline{\text { http://journal.iaimsinjai.ac.id/index.php/al-qalam }}$

Dengan demikian, pelajar, guru, dan orang tua menjadi kecewa dengan kegagalan tersebut. Kondisi ini membuat pelajar seringkali meninggakan sekolah daripada mengikuti kembali belajar. Industri menyebutnya sisa pekerjaan (scrap) dan kita menyebutnya putus sekolah (dropping out). Oleh karena itu, proses pembelajaran yang baik, pekerjaan yang baik dan pekerja yang baik harus diintegrasikan guna mengikis tinggal kelas, mengulang kelas dan kegagalan belajar. ${ }^{24}$ Apabila manajemen pendidikan Islam dikelola dengan baik, maka pendidikan Islam yang diharapkan, yaitu kemampuan intelektual, kebersihan hati dan keterampilan akan mampu diraih.

Berdasarkan hal tersebut, dapat dipahami bahwa upaya pendidikan Islam untuk menjawab problematika pendidikan, baik masa sekarang maupun di masa yang akan datang, harus berawal dari perbaikan sistem informasi manajemennya. Hal ini disebabkan karena hanya dengan perbaikan sistem manajamen penyelenggaraan pendidikan Islamlah yang mampu menjawab tantangan pendidikan masa depan yang bertumpu pada aspek efektifitas, efisiensi, dan relevansi. Betapa tidak, pendidikan Islam senantiasa bertumpu pada nilai-nilai ilhiyah sebagai basis pembelajarannya. Hal ini merupakan modal terbesar yang dimiliki oleh pendidikan Islam di bandingkan dengan pendidikan sekuler. Jadi, manakala pendidikan Islam mampu menjawab tantangan pendidikan sekarang dan memenuhi harapan stakeholdersnya, maka pendidikan akan menjadi mercusuar karena pada satu sisi konten pendidikan Islam adalah nilai-nilai ilahiyah dan di sisi lain memenuhi kebutuhan duniawiyah pesrta didik.

\section{KESIMPULAN}

Untuk mewujudkan peradaban yang maju, maka pendidikan dituntut untuk senantiasa berbenah dan berakselerasi dengan perubahan zaman. Terutama pendidikan Islam yang notabene merupakan sistem pendidikan yang telah ada jauh sebelum penetrasi kolonialisme di Indonesia. Sebagai institusi yang telah berumur, seyogyanya pendidikan Islam menjadi pendidikan yang paling diminati oleh seluruh masyarakat. Namun, kenyataannya tidak demikian. Pendidikan Islam harus berupaya untuk mengasimilisasikan antara ajaran ukhrawi dan tuntutan duniawi pelanggan pendidikan. Dengan demikian, tugas utama pendidikan Islam adalah menjawab tantangan peradaban yang semakin berkembang yang ditandai dengan munculnya masa yang disebutkan oleh Harold G. Shane sebagai masa depan sosio, masa depan tekno, dan masa depan bio.

${ }^{24}$ ibid, h. 39 


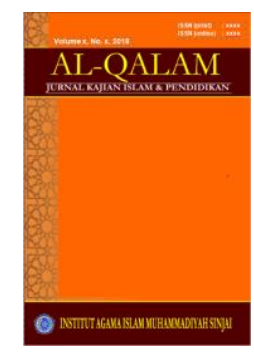

AL-QALAM

Jurnall Kajian Islam \& Pendidikan

Volume 06 No 022014

ISSN (print) : 1858-4152

ISSN (online) : -

Homepage : http://journal.iaimsinjai.ac.id/index.php/al-qalam

\section{DAFTAR PUSTAKA}

Alquranul karim dan terjemahnya

Arifin, M. Kafita Selekta Pendidikan Islam dan Umum Cet. IV, Jakarta : Bumi Aksara, 2000

Azra, Azyumardi, Esei-esei Intelektual Muslim dan pendidikan Islam, Cet. I, Jakarta : PT. Logos Wacana ilmu, 1999

Bungin, Burhan, Erotika Media Massa, Cet. I, Surakarta, Muhammadiyah University Perss, 2001

Dhiyauddin Umari, Arkam, Masyarakat Madani,tinjauan histories kehidupan Nabi, Cet. II, Jakarta : Gema Insani, 1999

Mulyasa, M. Kurikulum Bebasis Kompetensi, Konsep, Karakteristik dan Inplemaentasi, Cet. III, Bandung : Remaja Rosdakarya, 2003

Shaleh Abdullah, Abdurahman, Teori-teori Pendidikan berdasrkan Al-quran, Cet. II, Jakarta : Rineka Cipta, 1994

Syafaruddin, Manajemen Mutu Terpadu dalam pendidikan, konsep, strategi dan aplikasi, Cet. I, Jakarta : Grasindo, 2002

Tafsir, Ahmad, Ilmu Pendidikan dalam perspektif Islam, Cet. III, bandung: Remaja Rosdakarya, 2000 